\title{
A new comprehensive approach to characterizing carbonaceous aerosol with an application to wintertime Fresno, California $\mathbf{P M}_{2.5}$
}

\author{
P. Herckes ${ }^{1}$, J. A. Leenheer ${ }^{2}$, and J. L. Collett Jr. ${ }^{3}$ \\ ${ }^{1}$ Arizona State University, Department of Chemistry and Biochemistry, Tempe, AZ \\ 85287-1604, USA \\ ${ }^{2}$ U.S. Geological Survey, Building 95, MS408, Federal Center, Denver, CO 80225, USA \\ ${ }^{3}$ Colorado State University, Department of Atmospheric Science, Fort Collins, CO \\ 80523-1371, USA
}

Received: 23 April 2007 - Accepted: 9 June 2007 - Published: 19 June 2007

Correspondence to: P. Herckes (pierre.herckes@asu.edu)

\begin{abstract}
Fine particulate matter $\left(\mathrm{PM}_{2.5}\right)$ samples were collected during a three week winter period in Fresno (CA). A composite sample was characterized by isolating several distinct fractions and characterizing them by infrared and nuclear magnetic resonance (NMR) 5 spectroscopy. More than $80 \%$ of the organic matter in the aerosol samples was recovered and characterized. Only $35 \%$ of the organic matter was water soluble with another third soluble in dichloromethane and the remainder insoluble. Within the isolated water soluble material, hydrophobic acid and hydrophilic acids plus neutrals fractions contained the largest amounts of carbon. The hydrophobic acids fraction appears to con-

10 tain significant amounts of lignin type structures, spectra of the hydrophilic acids plus neutrals fraction are indicative of carbohydrates and secondary organic material. The dichloromethane soluble fraction contains a variety of organic compound families typical of many previous studies of organic aerosol speciation, including alkanes, alkanols, alkanals and alkanoic acids. Finally the water and solvent insoluble fraction exhibits a 15 strong aromaticity as one would expect from black or elemental carbon like material; however, these spectra also show a substantial amount of aliphaticity consistent with linear side chains on the aromatic structures.
\end{abstract}

\section{Introduction}

Carbonaceous material is an important component of ambient particulate matter. In many environments carbon contributes several $\mu \mathrm{g} / \mathrm{m}^{3}$ to ambient aerosol loadings (Malm et al., 2004). Despite its importance on global (climate) and local (visibility, health effects) scales (Kanakidou et al., 2005; Turpin et al., 2000), organic material has only in the past decade or so become a topic of systematic investigation.

For many years specific, usually toxic, species including polycyclic aromatic hydrocarbons or dioxins were studied in the particulate phase. More detailed speciation studies followed, characterizing some 200 species, including so called molecular markers 
used for aerosol source apportionment (e.g. Rogge et al., 1993; Schauer et al., 1996). Despite the large number of species quantified in source apportionment studies, they frequently account for less than $20 \%$ by mass of the total organic matter present (Brown et al., 2002), the remainder being largely uncharacterized.

5 In recent years some efforts have also been directed towards comprehensive approaches to characterizing particulate organic matter, focusing on bulk compound properties rather than on detailed molecular speciation. This general approach promises to provide more insight into modeling carbonaceous aerosol behavior in the atmosphere and, hopefully, to point out fruitful directions for future molecular speciation efforts.

10 Some of the approaches taken include investigating solubility (Decesari et al., 2001), structure (Gelencser et al., 2000), functionality (Decesari et al., 2000; Graham et al., 2002; Maria et al., 2002; Reff et al., 2005; Suzuki et al., 2001), and molecular size (Kalberer et al., 2004). Several studies investigated the fraction of organic particulate matter that is water-soluble to better understand the hygroscopic growth potential

15 of these particles and likely impacts on cloud and haze formation. In some cases the water soluble organic carbon (WSOC) was further analyzed by chromatographic and/or spectroscopic techniques (Chang et al., 2005; Decesari et al., 2000; Duarte et al., 2004, 2005; Graham et al., 2002; Kiss et al., 2002; Sullivan and Weber, 2006a; Sullivan and Weber, 2006b).

$20 \quad$ Early organic matter characterization efforts by Havers and co-workers concluded that carbonaceous aerosol, or a fraction thereof, shows properties similar to humic substances and the terminology HUmic Llke Substances (HULIS) was introduced (Havers et al., 1998). Many efforts have focused since on demonstrating similarities or differences between aerosol carbon and soil carbon, as extensively discussed by Graber and Rudich (2006). Recent work has also suggested that polymeric or oligomeric material, potentially from secondary atmospheric formation, might comprise a substantial component of ambient particulate matter(Gao et al., 2004; Kalberer et al., 2004; Samburova et al., 2005a; Samburova et al., 2005b; Tolocka et al., 2004).

As our understanding of the nature of carbonaceous particles has improved, some

$$
8425
$$

investigators have attempted to formulate simplified models of organic aerosol composition that would be useful conceptually as well as for use in both laboratory and numerical modeling studies. Among these efforts is the work by Fuzzi et al. (2001) and McFiggans et al. (2005).

5 In order to continue improving our understanding of carbonaceous aerosol, and to suggest fruitful directions for future organic speciation efforts, an approach previously developed for organic matter characterization in surface waters (Leenheer et al., 2000) and applied recently for fog organic matter (Herckes et al., 2007) was applied to atmospheric aerosol. Aerosol samples were collected in Fresno, California. A composite sample was characterized by fractionating and isolating organic matter into several classes based upon molecule size, solubility, polarity, and acid/base/neutral characteristics. Resulting organic isolates were then characterized by infrared and ${ }^{13} \mathrm{C}$-nuclear magnetic resonance (NMR) spectrometry and elemental analyses. Observed characteristics of the aerosol are reported here and compared with previous organic aerosol models.

\section{Experimental methods}

\subsection{Sampling}

Ambient aerosol samples were collected at five locations in the city of Fresno, California from 24 December 2003 until 15 January 2004. A detailed description of the 20 sampling protocols and concentrations of organic source marker species is given elsewhere (Gorin et al., 2006). In brief, the five sites included an urban site (downtown Fresno), three residential sites (California State University, Fresno campus; Fresno Pacific University campus and Clovis) and one site located in an industrial park in south Fresno near state highway 99. High-volume collectors were operated at all five sites to 25 collect 20 -h samples at a nominal flow rate of $1.13 \mathrm{~m}^{3} / \mathrm{min}$, periodically checked with a Thermo Andersen high-volume sampler calibration kit. The instruments were operated 
from 02:00 p.m. to 10:00 a.m., local time, to allow sufficient time for daily filter exchange by a single site operator at all sites. The period of collection might bias the $20-\mathrm{h}$ average sample concentrations somewhat higher than a 24-h average as local diurnal trends in winter $\mathrm{PM}_{2.5}$ concentrations demonstrate that from 10:00 a.m. to 02:00 p.m. concentra5 tions are typically at a minimum (Chow et al., 1999). All samplers were equipped with a Tisch Series $231 \mathrm{PM}_{2.5}$ impactor plate, providing simultaneous coarse particle samples (on a slotted pre-filter) and $\mathrm{PM}_{2.5}$ samples. At two sites (Drummond and Clovis) the high-volume collector was equipped with a $\mathrm{PM}_{10}$ inlet upstream of the $\mathrm{PM}_{2.5}$ impactor. In the current study we only focused on $\mathrm{PM}_{2.5}$ samples.

10 Total as well as organic and elemental carbon were determined on each individual filter using a thermo optical transmission method (Birch and Cary, 1996) on a Sunset Laboratories carbon analyzer. In order to provide enough particulate organic carbon for fractionation and analysis, a single composite sample was prepared by combining portions of each of the individual $\mathrm{PM}_{2.5}$ filters. Observations of aerosol composition, 15 therefore, should be interpreted as being representative of a cross-section of Fresno urban and suburban environments during winter.

\subsection{Preparative organic matter fractionation and isolation procedure}

The overall sample processing is described in Fig. 1 and is patterned after protocols used previously to characterize surface waters (Leenheer et al., 2000, 2004). 96 quartz iber filter sections, $1 / 8$ of each collected $\mathrm{PM}_{2.5}$ sample, were divided into smaller portions that were inserted into six $250 \mathrm{~mL}$ Teflon centrifuge bottles. A solution of $200 \mathrm{~mL}$ of $0.01 \mathrm{M} \mathrm{HCl}$ was added to each centrifuge bottle, and the bottles were mixed by rotating on a GlasCol laboratory rotator overnight. The acid solutions were decanted and vacuum-filtered through a $47 \mathrm{~mm}, 1 \mu \mathrm{m}$ porosity glass fiber filter. $200 \mathrm{~mL}$ of deionized

25 water were added to each bottle, the bottles rotated for one hour, and the water solutions decanted, filtered, and combined with the acid solution. This water extract was vacuum rotary evaporated to approximately $20 \mathrm{~mL}$. The distillate containing volatile organic acids was titrated to $\mathrm{pH} 8.0$ with $0.1 \mathrm{M} \mathrm{NaOH}$. This distillate was vacuum evap8427

orated and freeze-dried to isolate the sodium salts of volatile organic acids.

The $20 \mathrm{~mL}$ water extract was placed in a Spectra/Por 3 regenerated cellulose dialysis bag ( $29 \mathrm{~mm}$ diameter, 3500 dalton pore size cutoff). It was dialyzed for three days against $1.1 \mathrm{~L}$ of deionized water. The particulate fraction in the dialysis bag was freeze5 dried to give a colloid fraction free from salts.

The glass fiber filters used to filter the water extract were added to the quartz fiber filters in the centrifuge bottles, and the filters were freeze-dried while in the centrifuge bottles. Methylene chloride $(100 \mathrm{~mL})$ was added to each centrifuge bottle and the sample was placed on the sample rotator overnight. The methylene chloride was vacuum10 filtered through a $47 \mathrm{~mm}, 1 \mu \mathrm{m}$ porosity glass fiber filter, and was vacuum rotary evaporated to $5 \mathrm{~mL}$. This $5 \mathrm{~mL}$ concentrate was transferred to a $5 \mathrm{~mL}$ glass vial and was blown down to dryness under a stream of nitrogen gas. This fraction is designated $\mathrm{CH}_{2} \mathrm{Cl}_{2}$-extractable organic matter.

The quartz fiber filters in the six centrifuge bottles and the glass fiber filters used 15 to filter the water and methylene chloride extracts were transferred to six Spectra/Por 3 regenerated cellulose dialysis bags $(29 \mathrm{~mm}$ diameter, 3500 dalton pore size cutoff), and each bag was dialyzed against $4 \mathrm{~L}$ of $0.2 \mathrm{M} \mathrm{HF}$. The HF solutions were changed daily for four days until the filters were completely dissolved. The bags were then dialyzed against deionized water until the permeate specific conductance was less

20 than $10 \mu \mathrm{S} / \mathrm{cm}$, and the particulate suspension inside the bags was freeze-dried to isolate the particulate organic matterfraction.

The $1.1 \mathrm{~L}$ of dialysis permeate from the water extract was passed through a $20 \mathrm{~mL}$ column $(1 \mathrm{~cm}$ ID $\times 28.5 \mathrm{~cm})$ of MSC-1H cation exchange resin. The resin was rinsed with $50 \mathrm{~mL}$ of deionized water and then desorbed with $50 \mathrm{~mL}$ of $75 \%$ acetonitrile/25\%

25 water. This solution was evaporated and freeze-dried to isolate the hydrophobic neutral fraction. The MSC-1H column was then desorbed with $50 \mathrm{~mL}$ of $3 \mathrm{M} \mathrm{NH}_{4} \mathrm{OH}$ which was evaporated and freeze dried to isolate the base fraction. The sample and rinse effluents from the MSC-1H column were then passed through a $20 \mathrm{~mL}$ column ( $1 \mathrm{~cm} \mathrm{ID}$ $\times 28.5 \mathrm{~cm}$ ) of Amberlite XAD-8 resin followed by $50 \mathrm{~mL}$ of $0.01 \mathrm{M} \mathrm{HCl}$ rinse. The column 
was desorbed with $50 \mathrm{~mL}$ of $75 \%$ acetonitrile/25\% water. This solution was evaporated and freeze-dried to isolate a hydrophobic acid fraction.

The $\mathrm{pH}$ of the sample and $\mathrm{HCl}$ rinse from the column effluent was adjusted to $\mathrm{pH}$ 5 with $\mathrm{NaOH}$. The volume was then reduced to $100 \mathrm{~mL}$ by vacuum rotary evapora5 tion in a large Buchi R-220 vacuum rotary evaporator. The sample was transferred to a small Buchi R-111 vacuum rotary evaporator and most of the $\mathrm{NaCl}, \mathrm{KCl}, \mathrm{Na}_{2} \mathrm{SO}_{4}$, and $\mathrm{CaSO}_{4}$ was removed by a zeotrophic distillation procedure (Leenheer et al., 2000) in which water from the sample is evaporated from glacial acetic acid, and inorganic salts are removed by vacuum filtration through a $1 \mu \mathrm{m}$ glass fiber filter while hydrophilic

10 acids and neutrals remain in solution. The filtrate volume was diluted with an equal volume of deionized water and $30 \mathrm{~mL}$ of $1 \mathrm{M}$ barium formate was added to precipitate the remaining sulfate as barium sulfate which was removed by centrifugation. The precipitate was washed with $20 \mathrm{~mL}$ of $1.0 \mathrm{M} \mathrm{HCl}$, separated by centrifugation, and the supernatant was evaporated to dryness with acetonitrile to remove $\mathrm{HCl}$. The dry wash

15 residue was added to the supernatant from the first centrifugation step. Excess barium in the supernatant was removed by passing the supernatant through an $80 \mathrm{~mL}$ $(1.5 \mathrm{~cm}$ inside diameter (ID) $\times 30 \mathrm{~cm}$ in length) $\mathrm{MSC}-1 \mathrm{H}$ cation-exchange resin column at a flow rate of $20 \mathrm{~mL} / \mathrm{min}$. The column effluent was vacuum evaporated to dryness by repeatedly adding anhydrous acetonitrile to the moist residue which removed water,

$20 \mathrm{HCl}$, acetic acid and formic acid as volatile azeotrophs with acetonitrile. Fifty milliliters of $98 \%$ formic acid was added to the dry residue and evaporated to dryness. This process reduces nitric acid in the sample to volatile nitrogen dioxide which is removed during evaporation. Formic acid in the moist residue was removed by evaporation with acetonitrile, and $50 \mathrm{ml}$ of methanol was added and evaporated to dryness to remove boric acid as volatile trimethyl borate. The residue was dissolved in $5.0 \mathrm{~mL}$ water and saturated $\mathrm{LiOH}$ was added to adjust to $\mathrm{pH} 12$ to precipitate $\mathrm{Li}_{3} \mathrm{PO}_{4}$. The solution was vacuum filtered through a $1 \mu \mathrm{m}$ glass fiber filter and excess lithium was removed with a $20 \mathrm{~mL}$ MSC-1H cation exchange resin column $(1 \mathrm{~cm}$ inside diameter $\times 28.5 \mathrm{~cm}$ in length). The column effluent was freeze-dried to isolate a Hydrophilic acids plus

8429

neutrals fraction.

\subsection{Chemical characterization}

\subsubsection{Fourier Transform-Infrared (FT-IR) Spectrometry}

Infrared spectra were collected using 1-2 mg of organic matter fraction isolates in 5 potassium bromide pellets. A Perkin Elmer System 2000 FT-IR, using an infrared source with a pulsed laser carrier and a deuterated triglycine sulfate detector, scanned from 4000 to $400 \mathrm{~cm}^{-1}$, averaging 10 scans at $1.0 \mathrm{~cm}^{-1}$ intervals with a resolution of $4.0 \mathrm{~cm}^{-1}$. All spectra were normalized after acquisition to a maximum absorbance of 1.0 for comparative purposes. For peak frequency assignments for organic compound

- classes see Table 1; assignments for inorganic solutes commonly found in water samples are given in Table 2.

2.3.2 Solid state cross polarization magic angle spinning ${ }^{13} \mathrm{C}-$ Nuclear Magnetic Resonance (NMR) Spectrometry

Solid State Cross Polarization Magic Angle Spinning (CPMAS) ${ }^{13}$ CNMR spectra were obtained on $10 \mathrm{mg}$ or greater masses of organic matter fractions. Freeze-dried samples were packed in ceramic rotors. CPMAS ${ }^{13} \mathrm{C}$-NMR spectra were obtained on a 200megahertz $(\mathrm{MHz})$ Chemagnetics $\mathrm{CMX}$ spectrometer with a $7.5-\mathrm{mm}$-diameter probe. The spinning rate was $5000 \mathrm{~Hz}$. The acquisition parameters included a contact time of $5 \mathrm{~ms}$, pulse delay of $1 \mathrm{~s}$, and a pulse width of $4.5 \mu \mathrm{s}$ for the $90^{\circ}$ pulse. Variable contact 20 time studies and comparison of liquid-state with solid state ${ }^{13} \mathrm{C}-\mathrm{NMR}$ spectra by Wershaw and coworkers (Wershaw et al., 2000) indicate these are the optimum parameters for quantitatively determining different organic carbon structural group contributions to the NMR spectra. The small fraction masses and hydroscopic nature of certain sample fractions created difficulties in obtaining ${ }^{13} \mathrm{C}$-NMR spectra. Sample runs of two to three 25 days were required to obtain ${ }^{13} \mathrm{C}-\mathrm{NMR}$ spectra with adequate signal to noise ratios. 
Organic structural assignments for peaks in the CPMAS ${ }^{13} \mathrm{C}-\mathrm{NMR}$ spectra are given in Table 3.

\subsubsection{Elemental analyses}

Elemental analyses $(\mathrm{C}, \mathrm{H}, \mathrm{N})$ and moisture content of organic matter fractions were 5 conducted by Huffman Laboratories, Golden, Colorado (Huffman and Stuber, 1985). The small fraction masses created some difficulties in obtaining complete elemental and moisture analyses. Moisture and nitrogen contents were omitted when there was insufficient material available to analyze.

\section{Results and discussion}

10 The fractionation procedure described above isolates carbon in the samples from inorganic salts, mineral components, and quartz fiber filters. The sample is fractionated into more homogeneous fractions based upon molecule size, polarity, volatility, and acid/base/neutral properties. The infrared and ${ }^{13} \mathrm{C}-\mathrm{NMR}$ spectra and elemental analyses yield complementary organic structural information at a compound-class level for

15 each of the isolated fractions. Both the experimental approach and resulting information are unique, yielding original information on the composition of organic matter in Fresno winter aerosol.

Fraction weights and elemental analyses of organic matter fractions from the composite Fresno aerosol sample are presented in Table 4. A bar diagram of the total 20 organic carbon fractionation is presented in Fig. 2. The largest fractions of carbon are represented by the particulate organic matter fraction and the $\mathrm{CH}_{2} \mathrm{Cl}_{2}$ extractable organic matter fraction, at 34 and $31 \%$, respectively. The hydrophilic acids plus neutrals fraction contained $12 \%$ of the carbon and the hydrophobic acids fraction $10 \%$. Other fractions individually contained $1-6 \%$ of the carbon recovered in the fractiona25 tion scheme.

$$
8431
$$

The total mass of organic carbon recovered by the organic matter fractionation procedure was $85.2 \mathrm{mg}$. The total organic carbon mass the quartz fiber filter composite was determined by the Sunset carbon analyzer measurements to be $102.3 \mathrm{mg}$ (total carbon mass was $122.4 \mathrm{mg}$ ). Therefore, the organic carbon recovery of the frac5 tionation procedure is $83 \%$. This recovery percentage is approximate because of the various corrections and estimates for certain fractions presented in Table 4. Moisture contents were not determined for these fractions so that sufficient fraction mass would be left for nitrogen determinations. Recovery of $83 \%$ of the organic carbon $(70 \%$ if one considers the total carbon) in the aerosol sample is quite good considering the - following two factors. First, the organic carbon mass of the sample is exceptionally small for a total organic carbon fractionation of this type. Handling and transfer losses tend to increase percentage carbon losses as the sample mass decreases. Second, semivolatile neutral compounds, such as alcohols, aldehydes, and ketones, might be lost during the fractionation and isolation procedure. The recovery seen here is also

15 comparable to other "comprehensive" approaches to particulate organic carbon characterization (Chang et al., 2005; Decesari et al., 2000; Graham et al., 2002).

The water soluble fractions account for $29.4 \mathrm{mg}$ of the $85.3 \mathrm{mg}$ of isolated material suggesting a WSOC fraction of $35 \%$. This percentage compares reasonably well with an independent determination of dissolved organic carbon (DOC) in a filter leachate 20 which estimated $25 \%$ of the organic carbon is soluble in water. The fraction of WSOC in Fresno aerosol samples is at the low end of the typical range of 35-80\% commonly reported in the literature (Alves et al., 2002; Decesari et al., 2001; Graham et al., 2002; Kiss et al., 2002). Highly polluted urban areas, however, tend to have a lower fraction of water soluble organic particulates since freshly emitted carbonaceous particles,

25 especially from combustion processes, tend to be more hydrophobic than processed aerosol particles or secondary organic species. The absence of chemically aged particles is probably enhanced by reduced photochemistry in the winter time period studied here. Second, Fresno experiences frequent fog and haze conditions in winter and saw a substantial amount of precipitation and drizzle during the study period (Collett et al., 
2007; Gorin et al., 2006). Under these conditions, the water soluble species are preferentially scavenged and removed from the atmosphere. Finally, fresh wood combustion is a major source of the ambient particle particulate matter observed in Fresno during the study period (Gorin et al., 2006). The main combustion source is fireplace and

5 woodstove emissions. Flaming combustion, common in fireplaces, exhibits a WSOC fraction as low as 4\% (Novakov and Corrigan, 1996) while smoldering conditions, like those in large biomass burning events commonly yield a much higher WSOC fraction (Graham et al., 2002).

The particulate organic matter fraction is the largest fraction in the aerosol sample

10 (Fig. 2). The isolated fraction appeared black, having substantial (35.6\%) aromatic (elemental) carbon content based upon the ${ }^{13} \mathrm{C}-\mathrm{NMR}$ spectrum of Fig. 3. The elemental carbon content determined by ${ }^{13} \mathrm{C}$-NMR spectrometry is $10.2 \mathrm{mg}$, about half the content $(20.1 \mathrm{mg})$ of elemental carbon directly determined on the quartz fiber filters by the NIOSH method (Birch and Cary, 1996). The infrared spectrum (Fig. 4) of this fraction

15 is free from any bands indicating inorganic substances such as the quartz fiber filter in which the aerosols were entrained. The sharp band at $2920 \mathrm{~cm}^{-1}$ and the sharp peak at $30 \mathrm{ppm}$ in the ${ }^{13} \mathrm{C}$-NMR spectrum are indicative of methylene groups in straight chain hydrocarbons. The band at $1700 \mathrm{~cm}^{-1}$ and small peak at $174 \mathrm{ppm}$ indicate the presence of carboxylic acid groups. The broad band near $1620 \mathrm{~cm}^{-1}$ in the infrared 20 spectrum indicates aromatic and hydrogen-bonded quinone groups.

The large difference in "elemental carbon" measured by the thermo-optical method in individual filters and the aromatic (elemental) carbon content measured in the particulate organic carbon fraction is intriguing. It is unlikely that such a large difference (approximately a factor of 2) can be explained by uncertainties associated with con25 structing the filter composite or by losses in the isolation procedure. More likely, a large fraction of what is measured as EC by the thermo-optical method is not a pure graphite (aromatic) structure but rather contains a substantial amount of other refractory organic material. EC is only operationally defined and its amount can vary largely with the analytical method used (Chow et al., 2001; Currie et al., 2002). The fact that a

\section{3}

large aliphatic component (shown in the ${ }^{13} \mathrm{C}-\mathrm{NMR}$ spectrum of Fig. 3) in the particulate organic matter fraction was not extractable with methylene chloride suggests that the aliphatic hydrocarbons are covalently bonded with the black carbon component, perhaps as the result of radical coupling reactions. Unfortunately our understanding of the 5 chemical structure of soot in general and aerosol EC in particular is poor. This is not a problem unique to the aerosol science community; black carbon has also recently been found to be overestimated in soils and sediments because of methodological artifacts (Simpson and Hatcher, 2004).

The $\mathrm{CH}_{2} \mathrm{Cl}_{2}$-extractable organic matter fraction is the second highest organic car10 bon mass fraction (see Fig. 2). The extractable organic matter in the sample consisted mainly of straight chain aliphatic hydrocarbons. These aliphatic hydrocarbons may be attached to carboxylic acid $\left(1710 \mathrm{~cm}^{-1}\right)$, ester $\left(1735 \mathrm{~cm}^{-1}\right)$, and aromatic $\left(1620 \mathrm{~cm}^{-1}\right)$ structures which contribute small peaks to the infrared spectrum of this fraction (Fig. 4). Many aerosol organic speciation studies use methylene chloride or similar solvents to 15 extract the organic fraction prior to GC/MS analysis. Hence solvent extractable fractions are well characterized and it has been shown that straight and branched alkanes, alkanols, alkanoic acids, and alkanals are substantial components of particulate organic matter (Alves et al., 2001; Fraser et al., 2002; Limbeck and Puxbaum, 1999; Rogge et al., 1993; Schauer et al., 1996). A more detailed discussion of the methylene chloride extractable fraction of these Fresno aerosol samples is given elsewhere (Gorin et al., 2006) and several other studies also addressed the solvent extractable fraction of Fresno aerosol (Poore, 2002; Schauer and Cass, 2000). Silicone bands (1260, 1100, 1053 and $804 \mathrm{~cm}^{-1}$ ) are also present in the methylene chloride extract fraction as a result of contamination by silicone lubricant used on the seals in the vacuum rotary

25 evaporator. The silicone bands are a minor mass contaminant as the organic carbon percentage of these silicone lubricants is about $33 \%$ whereas the organic carbon percentage of this fraction is $72.2 \%$ (Table 4). The organic carbon contribution by the silicone lubricants was estimated in Table 4 by measuring the ratio of the peak intensity at $2960 \mathrm{~cm}^{-1}$ (methyl groups in silicones) to the peak intensity at $2920 \mathrm{~cm}^{-1}$ (methy- 
lene groups in sample hydrocarbons) and calculating the relative contributions of silicone versus sample components based upon absorptivity ratios of standard compound spectra published by Pouchert (Pouchert, 1985). The organic carbon contribution with the silicones was calculated as $3.13 \mathrm{mg}$.

The volatile acid fraction in aerosol samples has substantially less percentage mass (Fig. 2) than in fog samples collected in this region (Herckes et al., 2007). This is not surprising given the high solubility of weak gas phase organic acids in high $\mathrm{pH}$ (6-8) Fresno fogwaters. The aerosol volatile acid fractions is also substantially different in that acetic acid (measured as acetate), which is the dominant volatile acid in

10 the fogwater samples (Ervens et al., 2003), is a major component (peak at 26 ppm in the ${ }^{13} \mathrm{C}$-NMR spectrum), but longer-chain (methylene peak at $30 \mathrm{ppm}$ ), and branched chain (methine peak at $38 \mathrm{ppm}$ and methyl peak at $14 \mathrm{ppm}$ ) acids are present as well. The broad peak at $72 \mathrm{ppm}$ might be indicative of volatile ether acids and the peak at $127 \mathrm{ppm}$ indicates the presence of volatile aromatic acids. Many low molecular weight

15 acids, including formic and acetic acid along with branched and aromatic species have been reported in speciation studies of atmospheric particulate matter (Falkovich et al., 2005; Souza et al., 1999). The NMR peak at $171 \mathrm{ppm}$ is indicative of sodium carbonate which is also indicated by the broad band at $1440 \mathrm{~cm}^{-1}$ in the infrared spectrum of Fig. 4. Sodium carbonate might result from drying this fraction at too high a pH value.

20 The mass of the colloid fraction, respresenting just $2 \%$ of the total recovered carbon, was sufficient only for an infrared spectrum (see Fig. 4). Inorganic sulfates are indicated by bands at 1125 and $607 \mathrm{~cm}^{-1}$; silicates are indicated by bands at 1095 and $460 \mathrm{~cm}^{-1}$. Organic-structure bands at 1720,1665, 1627, 1513, and $1413 \mathrm{~cm}^{-1}$ are suggestive of lignin structures (Faix, 1991). The hydrophobic neutral fraction contributes the smallest mass to the total organic carbon fractionation (1\%), and only an infrared spectrum (Fig. 4) was obtained. Organic-structure bands at 1720, 1630, 1515, 1280 and $1113 \mathrm{~cm}^{-1}$ are again suggestive of lignin structures (Faix, 1991); the differing position of these bands relative to the similar bands reported in the colloid fraction may reflect a greater degree of oxidation and degradation of lignins in the hydrophobic neu-

\section{5}

tral fraction. A small, sharp band at $1260 \mathrm{~cm}^{-1}$ suggests the presence of nitrate esters. Bands for nitrite esters and nitroso groups were not found in this fraction, in contrast to their presence in analysis of a Fresno composite fog sample collected over the study period (Herckes et al., 2007).

5 The hydrophobic acid fraction was isolated as a very "sticky" fraction which precluded obtaining a ${ }^{13} \mathrm{C}-\mathrm{NMR}$ spectrum; however, an infrared spectrum (Fig. 4) and elemental analyses (Table 4) were obtained. Sharp bands in the infrared spectrum at 1630 and $1280 \mathrm{~cm}^{-1}$ indicate nitrate esters. The nitrogen content of this fraction (1.95\%) is consistent with the presence of nitrate esters. Bands at 1515,1335 , and $1120 \mathrm{~cm}^{-1}$ may 10 indicate again degraded lignin components (Faix, 1991).

The colloid, hydrophobic neutral, and hydrophobic acid fractions all show aromatic structures suggestive of lignin precursors. Humic-like substances derived from lignintype precursors were reported to form in model cloud water (Hoffer et al., 2004). It is interesting that the lignin signal is stronger in the aerosol sample than in a fogwater

15 sample collected at this location (Herckes et al., 2007) where fulvic acid was found to be derived from terpenoid precursors. Possibly, the phenol groups in lignin are more susceptible to oxidative degradation than in terpenoids where the phenol content is much lower. Organic nitrate esters were also found in the hydrophobic neutral and hydrophobic acid fractions, consistent with earlier findings of Garnes and Allen (2002).

20 The hydrophilic acid plus neutral fraction contains the majority of the water-soluble organic carbon (Fig. 2). The infrared spectrum (Fig. 4) has a strong $\mathrm{C}-\mathrm{O}$ band at $1050 \mathrm{~cm}^{-1}$ and only a moderate carboxylic acid band at $1720 \mathrm{~cm}^{-1}$. The ratio of these two bands indicates that neutral components rich in aliphatic alcohols are greater than carboxylic acid components. The ${ }^{13} \mathrm{C}-\mathrm{NMR}$ spectrum (Fig. 3) indicates the fraction

25 is very rich in carbohydrates (anomeric carbon peak at $102 \mathrm{ppm}$ and alcohol peak at $72 \mathrm{ppm}$ ) this could be indicative of carbohydrates and anhydrosugars. The presence of a substantial amount of anhydrosugars, including levoglucosan, is consistent with separate measurements made on individual sample filters in a joint speciation study (Gorin et al., 2006) in which levoglucosan concentrations averaged $0.6 \mu \mathrm{g} / \mathrm{m}^{3}$ and wood com- 
bustion emissions were demonstrated to be a dominant contributor to the collected aerosol. Previous studies have found levoglucosnan, a cellulose pyrolysis product, at concentrations up to $4.8 \%$ of the total organic carbon present (Schauer and Cass, 2000).

5 Both the infrared and the ${ }^{13} \mathrm{C}-\mathrm{NMR}$ spectra for the hydrophilic acid plus neutral fraction indicate the presence of structural methyl groups $\left(2960 \mathrm{~cm}^{-1}\right.$ band and $21 \mathrm{ppm}$ peak) that are not typically found in carbohydrate structures. Methylene hydrocarbon structures are indicated by the $2920 \mathrm{~cm}^{-1}$ band and $30 \mathrm{ppm}$ peak. No aromatic carbon structures are found in this fraction. A possible explanation for the presence of

10 branched methyl groups in this fraction is the formation of secondary organic aerosols through photooxidation of isoprene (Claeys et al., 2004). A number of methyl branchedchain polyols are formed through this atmospheric reaction, and their structures are consistent with spectral signatures in this fraction.

The base fraction is a relatively minor component of the Fresno aerosol (4\% of re-

15 covered carbon), but it is a fraction that is very rich is nitrogen (Table 4) with an atomic $\mathrm{C}: \mathrm{N}$ ratio of 3.5. The infrared spectrum (Fig. 4) of the base hydrochlorides does not show any indication of ammonium chloride; thus, the nitrogen content of this fraction is derived from the sample and not the ammonia eluent. The broad bands at 1720, 1600, and $1500 \mathrm{~cm}^{-1}$ are typical for a mixture of amino acids and peptides (Pouchert, 1985).

20 The plateau between 3200 and $3000 \mathrm{~cm}^{-1}$ are $\mathrm{N}-\mathrm{H}$ stretching modes of these amino acids and peptides. The atomic $\mathrm{C}: \mathrm{N}$ ratio also supports the amino acid and peptide assignment. Again the presence of these species is not surprising in the nitrogen rich environment of Fresno. Zhang and Anastasio have shown high concentrations of free and total amino acids in different locations in the Central Valley of California (Zhang and

25 Anastasio, 2003; Zhang et al., 2002). Separate measurements of dissolved organic nitrogen in Fresno fog samples collected during the study period confirm the importance of organic nitrogen in the area (Collett et al., 2007).

Comparing our results to other studies using fractionation techniques must be done with caution as other studies use different procedures and hence isolated fractions

8437

are not directly comparable. In addition, wintertime Fresno is a particular environment influenced by substantial agriculture emissions combined with dust, biomass burning (domestic wood burning) and vehicle emissions; frequently processed by local radiation fogs. The resulting fine carbonaceous material is only poorly water soluble. However 5 comparing our results with the model composition proposed by Fuzzi et al. (2001) for water soluble organic aerosol, there are many similarities. In our case a fulvic acid type material could reasonably represent $\sim 40 \%$ of the water soluble organic material as suggested by Fuzzi. Levoglucosan and polyol type material also have similar importance as in Fuzzi's model, although small organic acid molecules are less important in our case. Finally our observations reveal a higher organic nitrogen content than proposed for the aerosol model, perhaps reflecting different source types characteristic of the Fresno region.

Similar processing and analysis of organic material in Fresno fogs collected on several days during the same study (Herckes et al., 2007) permits an interesting compari-

15 son of the water soluble organic carbon (WSOC) fraction studied here with characteristics of the organic material actually scavenged by Fresno fog drops. Some important similarities and significant differences are both seen. The main organic fraction in both fog and $\mathrm{PM}_{2.5}$ WSOC are the hydrophilic acids, not surprising given their solubility and the likelihood that significant carbonaceous material is contributed to the fog drops by

20 nucleation scavenging. On the other hand the volatile acid fraction, mostly formic and acetic acid, is more important in fog droplets. As discussed above, this is not surprising given the high vapor pressure of these compounds which keep them mostly in the gas phase, except when high $\mathrm{pH}$ liquid water is available to dissolve them. We also note that the fog organic matter contained a substantial amount of biological organic ma-

25 terial (cell wall fragments, proteins, acetylaminosugars,...) while this was not seen in the $\mathrm{PM}_{2.5}$ aerosol fraction. This difference might result from fog scavenging of coarse particulate matter, rich in biological material, excluded from our $\mathrm{PM}_{2.5}$ analysis. Finally hydrophobic, lignin precursor-type material is less important in fog compared to $\mathrm{PM}_{2.5}$ WSOC and also appears to feature somewhat different structures in these two phases. 
This might reflect different formation pathways, although more investigation is certainly necessary to test such a hypothesis.

\section{Conclusions}

The organic composition of fine particulate matter was investigated in Fresno (CA)

5 during a 3 week winter period. A composite sample was characterized by isolating several distinct fractions and characterizing them by infrared and nuclear magnetic resonance (NMR) spectroscopy.

More than $80 \%$ of the organic carbon in the aerosol samples was recovered in the extraction and separation process and characterized. A majority of the organic matter was insoluble in water. The small water soluble organic carbon fraction (35\%) is consistent with local winter time conditions with fresh, local particle emissions from domestic wood burning and urban traffic as well as preferential removal of soluble material by frequent radiation fog episodes.

An insoluble carbon fraction, which did not dissolve in water or dichloromethane, 15 showed a strong aliphatic character paired with the expected aromaticity of this fraction which might be expected to reflect the presence of black carbon. Our results suggest that the aerosol black carbon is likely made up by aromatic structures associated with linear hydrocarbon chains. The methylene chloride soluble carbon fraction featured many spectral characteristics, typical of species commonly identified in speci20 ation studies using this solvent, including alkanes, alkanols and alkanoic acids.

The main water soluble organic carbon fraction, the hydrophilic acid fraction, exhibited characteristics suggestive of carbohydrates, compounds common in biomass emissions. Potential polyol type compounds, suggestive of the presence of secondary organic material, were also observed. Several other carbon fractions appeared to 25 contain phenolic material like lignin precursors, not unlike some suggested humic like structures.

Comparisons of the composition of the water soluble fraction of Fresno $\mathrm{PM}_{2.5}$ organic 8439

material showed a number of similarities to an earlier organic aerosol model published by Fuzzi et al. (2001), although greater amounts of nitrogen were found in Fresno particles. Comparison of the same water soluble fraction of $\mathrm{PM}_{2.5} \mathrm{OC}$ with $\mathrm{OC}$ in Fresno fog water revealed that both were dominated by hydrophilic acids. Uptake of water 5 soluble, low molecular weight carboxylic acids and the presence of greater amounts of biological material distinguished the fog water organic composition from the water soluble organic carbon particles that likely acted as cloud condensation nuclei.

Acknowledgements. We are grateful to T. Lee, and A. Simpson for field assistance. Loan of high-volume collectors and assistance procuring sampling sites by the SJV Air District and

10 the California Air Resources Board (CARB) is gratefully acknowledged. Support for this work was provided by the National Science Foundation (ATM-0222607). Additional support was provided by the San Joaquin Valleywide Air Pollution Study Agency and the San Joaquin Valley Air Pollution Control District. The statements and conclusions in this paper are those of the contractor and not necessarily those of the CARB, the San Joaquin Valleywide Air Pollution

15 Study Agency or its policy committee, their employees or their members. Any use of trade, firm and product names is for descriptive purposes only and does not imply endorsement by the U.S. Government.

\section{References}

Alves, C., Carvalho, A., and Pio, C.: Mass balance of organic carbon fractions in atmospheric aerosols, J. Geophys. Res., 107, 8345, doi:10.1029/2001JD000616, 2002.

Alves, C., Pio, C., and Duarte, A.: Composition of extractable organic matter of air particles from rural and urban Portuguese areas, Atmos. Environ., 35, 5485-5496, 2001.

Birch, M. E. and Cary, R. A.: Elemental carbon-based method for monitoring occupational exposures to particulate diesel exhaust, Aerosol Sci. Technol., 25, 221-241, 1996.

25 Brown, S. G., Herckes, P., Ashbaugh, L., Hannigan, M. P., Kreidenweis, S. M., and Collett, J. L.: Characterization of organic aerosol in Big Bend National Park, Texas. Atmos. Environ., 36, 5807-5818, 2002.

Chang, H., Herckes, P., and Collett, J. L.: On the use of anion exchange chromatography 
for the characterization of water soluble organic carbon, Geophys. Res. Lett., 32, L01810, doi:10.1029/2004GL021322, 2005.

Chow, J. C., Watson, J. G., Crow, D., Lowenthal, D. H., and Merrifield, T.: Comparison of IMPROVE and NIOSH carbon measurements, Aerosol Sci. Technol., 34, 23-34, 2001.

5 Chow, J. C., Watson, J. G., Lowenthal, D. H., Hackney, R., Magliano, K., Lehrman, D., and Smith, T.: Temporal variations of $\mathrm{PM}_{2.5}, \mathrm{PM} 10$, and gaseous precursors during the 1995 integrated monitoring study in central California, J. Air Waste Manage. Assoc., 49, 16-24, 1999.

Claeys, M., Wang, W., Ion, A. C., Kourtchev, I., Gelencser, A., and Maenhaut, W.: Formation of secondary organic aerosols from isoprene and its gas-phase oxidation products through reaction with hydrogen peroxide, Atmos. Environ., 38, 4093-4098, 2004.

Collett, J. L., Herckes, P., Youngster, S., and Lee, T.: Processing of atmospheric organic matter by California radiation fogs, Atmos. Res., in press, 2007.

Currie, L. A., Benner, B. A., Kessler, J. D., Klinedinst, D. B., Klouda, G. A., Marolf, J. V., Slater,

15 J. F., Wise, S. A., Cachier, H., Cary, R., Chow, J. C., Watson, J., Druffel, E. R. M., Masiello, C. A., Eglinton, T. I., Pearson, A., Reddy, C. M., Gustafsson, O., Quinn, J. G., Hartmann, P. C., Hedges, J. I., Prentice, K. M., Kirchstetter, T. W., Novakov, T., Puxbaum, H., and Schmid, $\mathrm{H}$.: A critical evaluation of interlaboratory data on total, elemental, and isotopic carbon in the carbonaceous particle reference material, NIST SRM 1649a, J. Res. Natl. Inst. Stand.

20 Technol., 107, 279-298, 2002.

Decesari, S., Facchini, M. C., Fuzzi, S., and Tagliavini, E.: Characterization of water-soluble organic compounds in atmospheric aerosol: A new approach, J. Geophys. Res., 105, 14811489, 2000.

Decesari, S., Facchini, M. C., Matta, E., Lettini, F., Mircea, M., Fuzzi, S., Tagliavini, E., and Putaud, J. P.: Chemical features and seasonal variation of fine aerosol water- soluble organic compounds in the Po Valley, Italy, Atmos. Environ., 35, 3691-3699, 2001.

Duarte, R., Pio, C. A., and Duarte, A. C.: Synchronous scan and excitation-emission matrix fluorescence spectroscopy of water-soluble organic compounds in atmospheric aerosols, J. Atmos. Chem., 48, 157-171, 2004.

30 Duarte, R., Pio, C. A., and Duarte, A. C.: Spectroscopic study of the water-soluble organic matter isolated from atmospheric aerosols collected under different atmospheric conditions, Anal. Chim. Acta, 530, 7-14, 2005.

Ervens, B., Herckes, P., Feingold, G., Lee, T., Collett, J. L., and Kreidenweis, S. M.: On the 8441

drop-size dependence of organic acid and formaldehyde concentrations in fog, J. Atmos. Chem., 46, 239-269, 2003.

Faix, O.: Classification Of Lignins From Different Botanical Origins By Ft-Ir Spectroscopy, Holzforschung, 45, 21-27, 1991.

5 Falkovich, A. H., Graber, E. R., Schkolnik, G., Rudich, Y., Maenhaut, W., and Artaxo, P.: Low molecular weight organic acids in aerosol particles from Rondonia, Brazil, during the biomass-burning, transition and wet periods, Atmos. Chem. Phys., 5, 781-797, 2005, http://www.atmos-chem-phys.net/5/781/2005/.

Fraser, M. P., Yue, Z. W., Tropp, R. J., Kohl, S. D., and Chow, J. C.: Molecular composition of organic fine particulate matter in Houston, TX. Atmos. Environ., 36, 5751-5758, 2002.

Fuzzi, S., Decesari, S., Facchini, M. C., Matta, E., Mircea, M., and Tagliavini, E.: A simplified model of the water soluble organic component of atmospheric aerosols, Geophys. Res. Lett., 28, 4079-4082, 2001.

Gao, S., Ng, N. L., Keywood, M., Varutbangkul, V., Bahreini, R., Nenes, A., He, J. W., Yoo, K. Y., Beauchamp, J. L., Hodyss, R. P., Flagan, R. C., and Seinfeld, J. H.: Particle phase acidity and oligomer formation in secondary organic aerosol, Environ. Sci. Technol., 38, 6582-6589, 2004.

Garnes, L. A. and Allen, D. T.: Size distributions of organonitrates in ambient aerosol collected in Houston, Texas. Aerosol Sci. Technol., 36, 983-992, 2002.

20 Gelencser, A., Meszaros, T., Blazso, M., Kiss, G., Krivacsy, Z., Molnar, A., and Meszaros, E. Structural characterisation of organic matter in fine tropospheric aerosol by pyrolysis-gas chromatography-mass spectrometry, J. Atmos. Chem., 37, 173-183, 2000.

Gorin, C. A., Collett, J. L., and Herckes, P.: Wood smoke contribution to winter aerosol in Fresno, CA, J. Air Waste Manage. Assoc., 56, 1584-1590, 2006.

25 Graber, E. R. and Rudich, Y.: Atmospheric HULIS: How humic-like are they? A comprehensive and critical review, Atmos. Chem. Phys., 6, 729-753, 2006, http://www.atmos-chem-phys.net/6/729/2006/.

Graham, B., Mayol-Bracero, O. L., Guyon, P., Roberts, G. C., Decesari, S., Facchini, M. C., Artaxo, P., Maenhaut, W., Koll, P., and Andreae, M. O.: Water-soluble organic compounds

30 in biomass burning aerosols over Amazonia - 1. Characterization by NMR and GC-MS, J. Geophys. Res., 107, 8047, doi:10.1029/2001JD000336, 2002.

Havers, N., Burba, P., Klockow, D., and Klockow-Beck, A.: Characterization of humic-like substances in airborne particulate matter by capillary electrophoresis, Chromatographia, 47, 
619-624, 1998.

Havers, N., Burba, P., Lambert, J., and Klockow, D.: Spectroscopic characterization of humiclike substances in airborne particulate matter, J. Atmos. Chem., 29, 45-54, 1998.

Herckes, P., Leenheer, J. A., and Collett, J. L.: Comprehensive Characterization of Atmospheric Organic Matter in Fresno, California Fog Water, Environ. Sci. Technol., 41, 393-399, 2007.

Huffman Jr., E. W. D. and Stuber, H. A.: Analytical methodology for elemental analysis of humic substances, in: Humic Substances in Soil Sediment, edited by: Aiken, G. R., McKnight, D. M., Wershaw, R. L., and MacCarthy, P., John Wiley and Sons, New York, pp. 433-455, 1985.

Kalberer, M., Paulsen, D., Sax, M., Steinbacher, M., Dommen, J., Prevot, A. S. H., Fisseha, R., Weingartner, E., Frankevich, V., Zenobi, R., and Baltensperger, U.: Identification of polymers as major components of atmospheric organic aerosols, Science, 303, 1659-1662, 2004.

Kanakidou, M., Seinfeld, J. H., Pandis, S. N., Barnes, I., Dentener, F. J., Facchini, M. C., Van Dingenen, R., Ervens, B., Nenes, A., Nielsen, C. J., Swietlicki, E., Putaud, J. P., Balkanski, Y., Fuzzi, S., Horth, J., Moortgat, G. K., Winterhalter, R., Myhre, C. E. L., Tsigaridis, K.,

15 Vignati, E., Stephanou, E. G., and Wilson, J.: Organic aerosol and global climate modelling: a review, Atmos. Chem. Phys., 5, 1053-1123, 2005, http://www.atmos-chem-phys.net/5/1053/2005/.

Kiss, G., Varga, B., Galambos, I., and Ganszky, I.: Characterization of water-soluble organic matter isolated from atmospheric fine aerosol, J. Geophys. Res., 107, 8339,

20 doi:10.1029/2001JD000603, 2002.

Leenheer, J. A., Croue, J. P., Benjamin, M., Korshin, G. V., Hwang, G. J., Bruchet, A., and Aiken, G. R.: Comprehensive Isolation of Natural Organic Matter from Water for Spectral Characterizations and Reactivity Testing, in: Natural Organic Matter and Disinfection ByProducts, edited by: Barrett, S. E., Krasner, A. W., and Amy, G. L., American Chemical Society, Washington, D.C., pp. 68-83, 2000.

Leenheer, J. A., Noyes, T. I., Rostad, C. E., and Davisson, M. L.: Characterization and origin of polar dissolved organic matter from the Great Salt Lake, Biogeochemistry, 69, 125-141, 2004.

Limbeck, A. and Puxbaum, H.: Organic acids in continental background aerosols, Atmos. Environ., 33, 1847-1852, 1999.

Malm, W. C., Schichtel, B. A., Pitchford, M. L., Ashbaugh, L. L., and Eldred, R. A.: Spatial and monthly trends in speciated fine particle concentration in the United States, J. Geophys. Res., 109, D03306, doi:10.1029/2003JD003739, 2004.

8443

Maria, S. F., Russell, L. M., Turpin, B. J., and Porcja, R. J.: FTIR measurements of functional groups and organic mass in aerosol samples over the Caribbean, Atmos. Environ., 36, 51855196, 2002.

McFiggans, G., Alfarra, M. R., Allan, J., Bower, K., Coe, H., Cubison, M., Topping, D., Williams, P., Decesari, S., Facchini, C., and Fuzzi, S.: Simplification of the representation of the organic component of atmospheric particulates, Faraday Discuss., 130, 341-362, 2005.

Novakov, T. and Corrigan, C. E.: Cloud condensation nucleus activity of the organic component of biomass smoke particles, Geophys. Res. Lett., 23, 2141-2144, 1996.

Poore, M. W.: Levoglucosan in $\mathrm{PM}_{2.5}$ at the Fresno supersite, J. Air Waste Manage. Assoc., $10 \quad 52,3-4,2002$.

Pouchert, C. J.: The Aldrich Library of FT-IR Spectra. The Aldrich Chemical Company Inc., Milwaukee, Wisconsin, 1985.

Reff, A., Turpin, B. J., Porcja, R. J., Giovennetti, R., Cui, W., Weisel, C. P., Zhang, J., Kwon, J., Alimokhtari, S., Morandi, M., Stock, T., Maberti, S., Colome, S., Winer, A., Shendell, D.,

15 Jones, J., and Farrar, C.: Functional group characterization of indoor, outdoor, and personal $\mathrm{PM}_{2.5}$ : results from RIOPA, Indoor Air, 15, 53-61, 2005.

Rogge, W. F., Mazurek, M. A., Hildemann, L. M., Cass, G. R., and Simoneit, B. R. T.: Quantification of Urban Organic Aerosols at a Molecular-Level - Identification, Abundance and Seasonal-Variation, Atmos. Environ., 27, 1309-1330, 1993.

20 Samburova, V., Szidat, S., Hueglin, C., Fisseha, R., Baltensperger, U., Zenobi, R., and Kalberer, M.: Seasonal variation of high-molecular-weight compounds in the water-soluble fraction of organic urban aerosols, J. Geophys. Res., 110, D23210, doi:10.1029/2005JD005910, 2005a.

Samburova, V., Zenobi, R., and Kalberer, M.: Characterization of high molecular weight compounds in urban atmospheric particles, Atmos. Chem. Phys., 5, 2163-2170, 2005b.

Schauer, J. J. and Cass, G. R.: Source apportionment of wintertime gas-phase and particlephase air pollutants using organic compounds as tracers, Environ. Sci. Technol., 34, 18211832, 2000.

Schauer, J. J., Rogge, W. F., Hildemann, L. M., Mazurek, M. A., and Cass, G. R.: Source

30 apportionment of airborne particulate matter using organic compounds as tracers, Atmos. Environ., 30, 3837-3855, 1996.

Simpson, M. J. and Hatcher, P. G.: Overestimates of black carbon in soils and sediments, Naturwissenschaften, 91, 436-440, 2004. 
Souza, S. R., Vasconcellos, P. C., and Carvalho, L. R. F.: Low molecular weight carboxylic acids in an urban atmosphere: Winter measurements in Sao Paulo City, Brazil, Atmos. Environ., 33, 2563-2574, 1999.

Sullivan, A. P. and Weber, R. J.: Chemical characterization of the ambient organic aerosol

5 soluble in water: 1. Isolation of hydrophobic and hydrophilic fractions with a XAD-8 resin, J. Geophys. Res., 111, D05314, doi:10.1029/2005JD006485, 2006a.

Sullivan, A. P. and Weber, R. J.: Chemical characterization of the ambient organic aerosol soluble in water: 2. Isolation of acid, neutral, and basic fractions by modified size-exclusion chromatography, J. Geophys. Res., 111, D05315, doi:10.1029/2005JD006486, 2006b.

10 Suzuki, Y., Kawakami, M., and Akasaka, K.: H-1 NMR application for characterizing watersoluble organic compounds in urban atmospheric particles, Environ. Sci. Technol., 35, 26562664, 2001.

Tolocka, M. P., Jang, M., Ginter, J. M., Cox, F. J., Kamens, R. M., and Johnston, M. V.: Formation of oligomers in secondary organic aerosol, Environ. Sci. Technol., 38, 1428-1434, 2004.

Turpin, B. J., Saxena, P., and Andrews, E.: Measuring and simulating particulate organics in the atmosphere: problems and prospects, Atmos. Environ., 34, 2983-3013, 2000.

Wershaw, R. L., Aiken, G. R., Leenheer, J. A., and Tregellas, J. R.: Structural-group quantitation by CP/MAS13C-NMR measurements of dissolved organic matter from natural waters, in: Humic substances: Versatile components of plants, soil, and water, edited by: Ghabbour, E. A. and Davis, G., Royal Society of Chemistry, Cambridge, England, pp. 63-81, 2000.

Zhang, Q. and Anastasio, C.: Free and combined amino compounds in atmospheric fine particles $\left(\mathrm{PM}_{2.5}\right)$ and fog waters from Northern California, Atmos. Environ., 37, 2247-2258, 2003.

Zhang, Q., Anastasio, C., and Jimemez-Cruz, M.: Water-soluble organic nitrogen in atmospheric fine particles $\left(\mathrm{PM}_{2.5}\right)$ from northern California, J. Geophys. Res., 107, 4112, doi:10.1029/2001JD000870, 2002.

Table 1. Infrared frequency bands for various structures in organic matter isolates.

\begin{tabular}{ll}
\hline Compound Class & $\begin{array}{l}\text { Frequencies }\left(\mathrm{cm}^{-1}\right), \text { Structure }(\phi=\text { aromatic car- } \\
\text { bon ring), and Elements }(\mathrm{C}=\text { carbon, } \mathrm{H}=\text { hydrogen, } \\
\mathrm{N}=\text { nitrogen, } \mathrm{O}=\text { oxygen })\end{array}$ \\
\hline Carbohydrates & $3400-3300(\mathrm{O}-\mathrm{H}), 1100-1000(\mathrm{C}-\mathrm{O})$ \\
Fulvic Acid & $3400-3300(\mathrm{O}-\mathrm{H}), 2700-2500(\mathrm{COOH}), 1760$ \\
& $(\mathrm{COOR}), 1720(\mathrm{COOH}), 1660-1630(\phi-\mathrm{C}=\mathrm{O})$, \\
& $1280-1150(\phi-\mathrm{O}, \mathrm{COOH})$ \\
Aliphatic Hydrocarbons & $2960\left(\mathrm{CH}_{3}\right), 2940\left(\mathrm{CH}_{2}\right), 1460\left(\mathrm{CH}_{2}\right), 1380\left(\mathrm{CH}_{3}\right)$ \\
Aromatic Hydrocarbons & $\sim 1,600(\phi), 1500(\phi), 700-900, \phi-\mathrm{H}$ \\
Proteins & $1660(\mathrm{Amide} 1$ band, N-C=O), 1,540 $($ Amide \\
& 2 band, N=C-O) \\
N-Acetyl Amino Sugars & $1660(\mathrm{Amide} 1$ band, N-C=O), 1,550 $($ Amide \\
& 2 band, N=C-O)1380 $(\mathrm{CH})$ \\
Lipids & $1760(\mathrm{COOR}), 1720(\mathrm{COOH}), 2960\left(\mathrm{CH}_{3}\right), 2940$ \\
& $(\mathrm{CH}), 1460(\mathrm{CH}), 1380\left(\mathrm{CH} \mathrm{H}_{3}\right)$ \\
Nitrate Esters & $1630(\mathrm{~N}=\mathrm{O}), 1280(\mathrm{~N}-\mathrm{O})$ \\
Nitrite Esters & $1650(\mathrm{~N}=\mathrm{O}), 1370(\mathrm{~N}-\mathrm{O})$ \\
Nitroso Groups & $1400-1300(\mathrm{~N}=\mathrm{O})$ \\
\hline
\end{tabular}


Table 2. Characteristic infrared spectral peaks of inorganic solutes (in $\mathrm{KBr}$ pellets.)

\begin{tabular}{ll}
\hline Inorganic Solute & Characteristic IR Peaks $\left(\mathrm{cm}^{-1}\right)$ \\
\hline Boric Acid & $3212,2260,1450,1194,548$ \\
Sodium Bicarbonate & $2541,1920,1695,1618,1307,1000,837,696$ \\
Sodium Carbonate & 1440,880 \\
Sodium Nitrate & 1385,838 \\
Phosphoric Acid & 1007,490 \\
Disodium Hydrogen Phosphate & $1159,1074,950,860,544,521$ \\
Silicic Acid & $1093,964,798,468$ \\
Sulfuric Acid & $1288,1176,1071,1012,889,852,617,577,455$ \\
Sodium Hydrogen Sulfate & $1251,1182,1046,865,607,577,481$ \\
Sodium Sulfate & $1122,640,608$ \\
\hline
\end{tabular}

Table 3. Structural assignments for ${ }^{13} \mathrm{C}-\mathrm{NMR}$ spectra.

\begin{tabular}{llr}
\hline \multicolumn{2}{c}{ CC, carbon; $\mathrm{H}$, hydrogen; N, sulfur; O, oxygen; S, sulfur; $\phi$, aromatic carbon ring] } \\
\hline $\begin{array}{l}\text { Chemical Linkage } \\
\text { Between Elements }\end{array}$ & Compound Type & $\begin{array}{r}\text { Chemical Shift Range } \\
\text { (parts per million) }\end{array}$ \\
\hline $\mathrm{C}-\mathrm{H}$ & Aliphatic Hydrocarbon & $0-55$ \\
$\mathrm{C}-\mathrm{N}$ & Amines, Amides, Proteins & $40-55$ \\
$\mathrm{O}-\mathrm{CH}_{3}$ & Methoxy Groups in Tannins and Lignins & $55-60$ \\
$\mathrm{C}-\mathrm{O}$ & Aliphatic Alcohols, Ethers, and Esters & $60-90$ \\
$\mathrm{O}-\mathrm{C}-\mathrm{O}$ & Anomeric Carbon in Carbohydrates, Lactols & $90-110$ \\
$\phi$ & Aromatic Carbon & $95-165$ \\
$\phi-\mathrm{O}$ & Aromatic Esters, Ethers, and Phenols & $135-165$ \\
$\phi-\mathrm{SO}_{3} \mathrm{H}$ & Aromatic Sulfonic Acids & $140-145$ \\
$\mathrm{O}=\mathrm{C}-\mathrm{O}, \mathrm{O}=\mathrm{C}-\mathrm{N}$ & Carboxylic Acids, Esters, Amides & $160-190$ \\
$\mathrm{O}=\mathrm{C}-\mathrm{C}=\mathrm{C}$ & Flavones, Quinones & $170-200$ \\
$\mathrm{O}=\mathrm{C}-\mathrm{C}$ & Aliphatic and Aromatic Ketones & $190-220$ \\
\hline
\end{tabular}


Table 4. Weight, and Elemental Analyses of Organic Matter Fractions from Fresno Aerosols (ND=Not Determined).

\begin{tabular}{|c|c|c|c|c|c|c|c|}
\hline Fraction & $\mathrm{mg}$ & Percent Carbon & Percent Hydrogen & Percent Nitrogen & Milligrams Carbon & $\begin{array}{l}\text { Corrected } \\
\text { Carbon } \\
\text { (mg) }\end{array}$ & $\% \mathrm{C}$ \\
\hline $\begin{array}{l}\text { Particulate } \\
\text { Organic } \\
\text { Matter }\end{array}$ & 49.4 & 60.83 & 4.65 & 2.37 & 30.05 & $28.8^{1}$ & 34 \\
\hline Colloids & 6.1 & ND & ND & ND & ND & $1.8^{1,2}$ & 2 \\
\hline $\begin{array}{l}\text { Volatile } \\
\text { Acids, } \quad \mathrm{Na} \\
\text { Salts }\end{array}$ & 72.2 & 8.53 & 0.58 & 0.45 & 6.16 & $4.8^{1,3}$ & 6 \\
\hline $\begin{array}{ll}\mathrm{CH}_{2} \mathrm{Cl}_{2} \quad \mathrm{Ex}- \\
\text { tractable } \\
\text { Organic } \\
\text { Matter }\end{array}$ & 38.3 & 78.69 & 9.07 & 0.66 & 30.13 & $27.0^{4}$ & 31 \\
\hline $\begin{array}{l}\text { Hydrophobic } \\
\text { Neutrals }\end{array}$ & 1.5 & ND & ND & ND & ND & $0.7^{1,2}$ & 1 \\
\hline $\begin{array}{l}\text { Hydrophobic } \\
\text { Acids }\end{array}$ & 19.3 & 45.56 & 5.24 & 1.95 & 8.79 & $8.5^{1}$ & 10 \\
\hline $\begin{array}{l}\text { Hydrophilic } \\
\text { Acids plus } \\
\text { Neutrals }\end{array}$ & 48.7 & 23.50 & 3.62 & 1.81 & 11.44 & $10.5^{1}$ & 12 \\
\hline Bases & 9.9 & 33.37 & 5.66 & 11.14 & 3.30 & $3.1^{1}$ & 4 \\
\hline
\end{tabular}

1. Corrected for estimated moisture content. Moisture estimate based upon moisture content of same fraction in isolated fractions from Fresno fog samples (Herckes et al., 2007)

2. Corrected for estimated carbon percentages. Carbon percentage estimate based upon same fraction in isolated fractions from Fresno fog samples (Herckes et al., 2007)

3. Corrected by subtraction of inorganic carbonate percentage determined from ${ }^{13} \mathrm{C}-\mathrm{NMR}$ spectra of Fig. 3 .

4. Corrected by subtraction of silicone organic carbon percentages estimated from the infrared spectrum of Fig. 4.

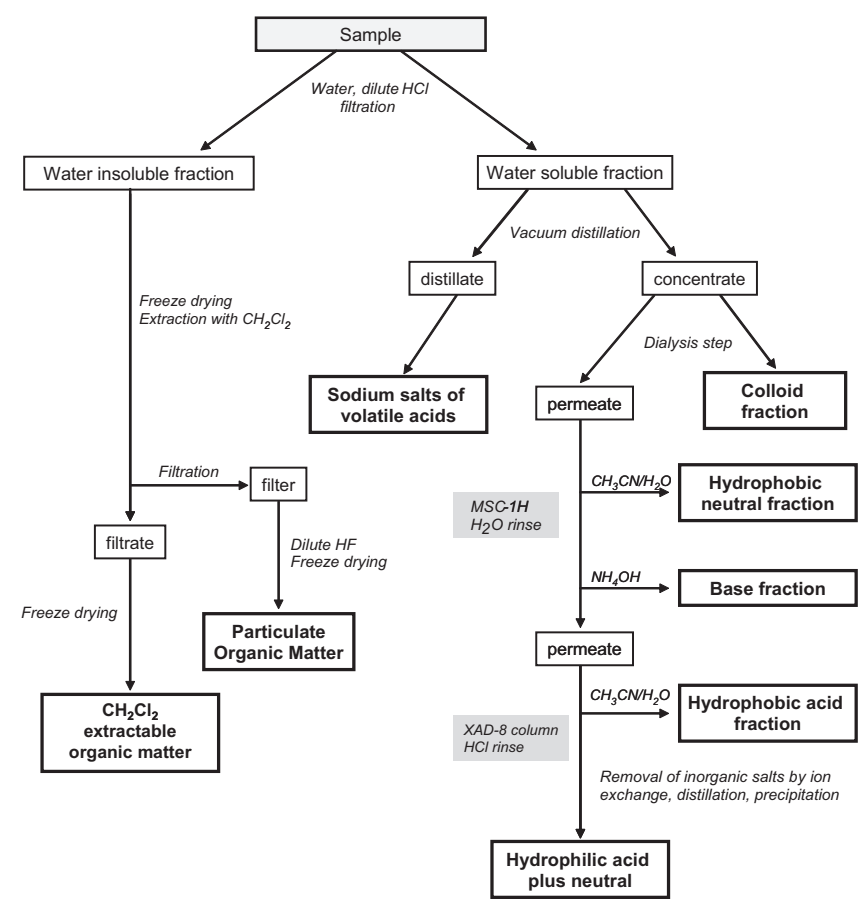

Fig. 1. Overview of isolation scheme. 


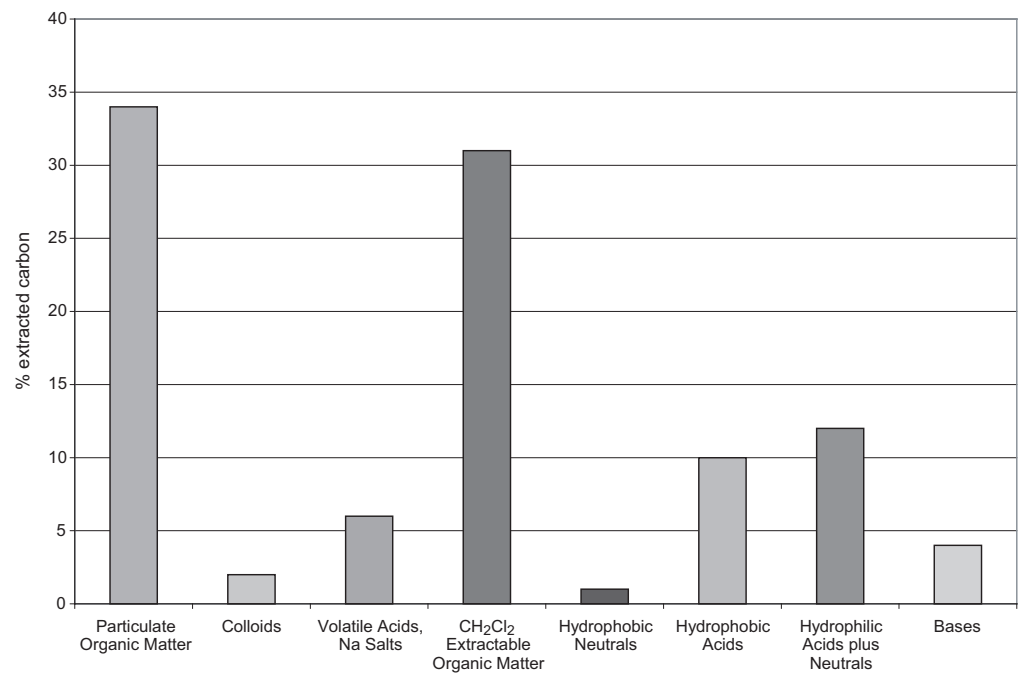

Fig. 2. Total organic carbon fractionation of Fresno aerosols.

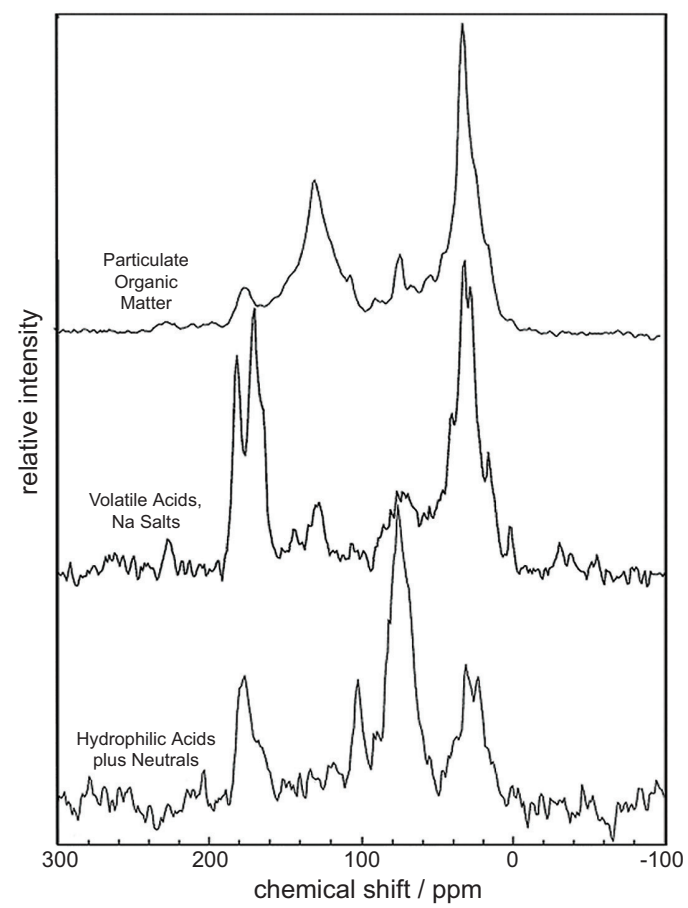

Fig. 3. ${ }^{13}$ C-NMR spectra of organic matter fractions from Fresno aerosols. 


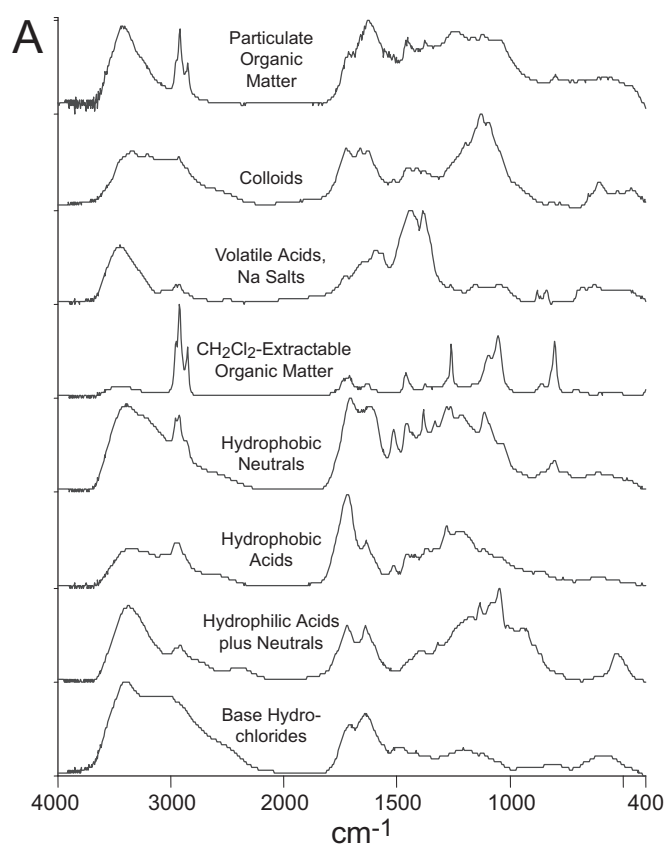

Fig. 4. Infrared spectra of organic matter fractions from Fresno aerosols. 